JoACHIM DieC

\title{
Conclusions
}

\section{The Deconstructive Power of the Russian Revolution}

The time that has passed since the beginning of the Russian Revolution is long enough to work out some interpretative formulas of its consequences. In the $19^{\text {th }}$ century, in his treaties about the Western world and Russia, the Russian poet and political thinker Fyodor Tyutchev (1803-1873) described the latter as the embodiment of an eternal providential empire whose mission is continually distorted by a diabolic power - the Revolution (Тютчев, 2013). As it turned out after a couple of decades, it was just Russia that became both the victim and the den of evil: the Revolution of 1917 took a specifically Russian shape even though it originally refuted the national idea.

In the course of time, the state that had grown on the revolutionary soil changed its image several times. According to Chaadaev's generalizations, which were mentioned in the introduction, Russia is abnormally vulnerable to radical transformations. This does not necessarily refer only to the great shifts of paradigms such as the Petrine reforms or the collapse of the old empire and the establishment of a communist state. Even within the Soviet period, everyday life and institutions looked significantly different in 1924, 1938, 1957 or in the 1970s. Dmitry Trenin realizes that in the very beginning the Russian Revolution 
was permeated by universalistic messianism. However, in the mid-1920s the paradigm of the Soviet state turned into a fortress mentality: the USSR was the only genuinely socialist country in the world (as it was in the case of the only Orthodox state - the Third Rome - in the $16^{\text {th }}$ century) surrounded by capitalist powers. After WW2, we dealt with "the socialist camp", and after 1960 with "the socialist community" which fought against the "world imperialism" with the United States at the helm. This competition led to longitudinal tension and to the collapse of the USSR in the end (Trenin, 2012, pp. 274-275).

Trying to answer the questions which were declared as the leitmotif of our study, we can initially point to the conclusion that the ideas, actions and consequences of the revolution result from a certain kind of unnaturalness. Its base is formed by the belief in the necessity of legal supremacy of ideas, such as the happiness of the people or the glory of a state or nation, over everyday needs and individual ambitions. The revolution originally fulfilled the dreams of several generations of Russian Marxists and Populists (Narodniki), who preached about the oppression which was experienced by the Russian people, especially peasants and workers. However, the new system managed to rob them of any individual property and individual rights. The life and dreams of the individual turned out to be trivial in the clash with the "just cause": a peasant who, just before WW1, was ultimately liberated from control and became the owner of his plot of land had to first face the duty of compulsory deliveries after 1917 and then, after 1928, the tragedy of collectivization.

Another source of unnaturalness lies in the conviction that the state (or any other collective organization) has a universal or divine mission. The pattern of such thinking comes from great religions, e.g. Shinto, Zoroastrianism, Judaism, Christianity or Islam. These missions, however, are generally oriented toward transcendental reality even if they concern human behavior and 
preoccupations. In the case of the Russian Revolution, contrary to most of the previous ones, it is a deterministic, post-Hegelian scheme that underlay the revolutionary actions and lawmaking. The assumption that the state might play an important part in the divine plan is close to the idea of the Byzantine diarchy or the Islamic caliphate, so one can seek some earlier patterns. Nevertheless, all of them treat the supernatural world as the main point of reference. In the case of the Marxist Revolution, the ultimate cause lies in the earthly state itself.

Such an attitude is linked to the idea that the essence of the mission can be expressed and successfully realized in laws and political actions. Law in the revolutionary perspective was treated neither as a set of practical regulations that can make the functioning of the state and society safer and more effective nor as a realization of a higher order. There was a lot of criticism of law in Russia under the old regime: it was usually accused of overregulation and allegiance to conservative values. However, the legal framework of the empire made it ineffective only in some way, whereas the Soviet law created a totally dysfunctional state, which finally collapsed after 70 years of totalitarian management. After the revolution, several legal solutions, as we can read in the first chapter, still influence today's Russian legislation, especially in the area of business and the relation of citizens with foreign legal and natural persons.

The essential place of law in the structure of Russia's dysfunctionality cannot be neglected. As a number of researchers have noted, law in Russia is perceived not as a core social value but as an instrument for the leaders. In the long history of the country, law was often criticized as a barrier to efficient policies. It is the central authority that is equipped with common trust and a providential mission. The same can be said about the advantage of politics over the economy. It is the central power that has always decided about the shape of economic relations. The situation is 
not very different in today's capitalist Russia, where all basic flows are controlled by the administration (Bieleń, 2014, pp. 211-212).

The unnaturalness of the main convictions in revolutionary thinking also stems from the belief that human needs are permanent and that there is an intelligible way in which we could meet them. The Russian Empire was authoritarian, not totalitarian, requiring obedience but not necessarily spiritual devotion (contrary to Pre-Petrine Moscovia). Some of the populist and revolutionary socialists, especially Petr Tkachov, postulated the standardization of needs and the physical liquidation of the older generation, which was supposed to be incapable of building a brave new and totally structuralized society. This kind of thinking was taken over by the Bolsheviks who created a political, economic and social system which lacked mental diversity. The system was uniform under the vertical leadership of the party, the economy was a leading example of inefficient central planning. In the area of culture and education, for a long time only the correct ideological (Marxist) and artistic (socialist realistic) lines were accepted. However, what seems paradoxical, it is the non-conformist activity that contributed to relative success in the USSR: the space breakthroughs, sport achievements or famous pieces in the movie industry or literature with Pasternak and Solzhenitsyn.

The second essential problem of the following study lies in the issue of equality: the problem of the people and of the elite. Whereas natural order (at least in the Hoppean explication) assumes a spontaneous emergence of nobilitas naturalis, the Bolshevik doctrine imposes different solutions. First of all, it aims at the creation of an entirely egalitarian society. This vision is by all means utopian but many studies on totalitarian utopias describe and cleverly generalize such phenomena. The Bolshevik dream neglects natural differences probably not only because it is a utopian idea. The attempt, which was doomed to fail from the very beginning, was in fact a powerful step toward the eradication 
of these disproportions. It was a dramatic struggle of those who were highly dissatisfied with the shape of the real world in which they were born: in the wrong country or ethnic group, in the wrong place or social class.

Measures were undertaken to even the social and economic status of Russian citizens: people of the lowest classes became officers and state officials, representatives of the nobility and bourgeoisie were expelled and even food was rationed at the very beginning of the Bolshevik era (according to the regulations of war communism). However, after a decade it turned out that there were some citizens who were more equal than others. Since the 1930s, the Stalinist regime consisted not only in the totalitarian dictatorship of one person but also in the power of the secret police, which had enormous prerogatives. Then, in the 1960s and 1970s the nomenklatura, a certain new class of well-established party officials, began to dominate in spite of the egalitarian ideology (Đilas, 1957). Even in the circumstances of such an ideological atmosphere, the system appeared incapable of any successful struggle against natural processes of the circulation of elites.

After the collapse of the red empire, in the 1990s, the Family (the people closest to President Boris Yeltsyn) and the oligarchs became the new elite of the "robbed country". Since 2000, the Putin team of secret service and military officials have established their supremacy in the name of the struggle against the old and bad oligarchy within the country and against the Western domination in international relations. In none of the cases has the Russian political system helped to work out a nobilitas naturalis that would be allowed to develop the country in an unrestricted way. The old oligarchs gained their property because of their connections with those who controlled the financial flows and decided about the economic shape of the country. However, they generally took advantage of their own smartness and initiative. The new elite predominantly used violence and restrictions subordinating the 
Russian economy to the expectations of statists but the level of inequality within the country became even more appalling.

This, in the end, makes us inquire about the relation between the revolution and the natural order. The notion of natural order includes several disputable aspects. First of all, it does not refer directly to the state of nature. Contrary to that, it combines two tendencies. On the one hand, it is based on realism concerning the laws of nature, i.e. human corporeality. On the other - it tries to meet something actually absent in nature: the need for harmonious development in the material and mental spheres. For some it might be the never ending search for the undefinable dào (道); for others - a quest for a life formed according to the biblical commandments and reflections: "fill the earth and subdue it" (Genesis, 1, 28), "For my thoughts are not your thoughts, neither are your ways my ways (Isaiah, 55, 8-9)" and St. Augustine's famous conviction that "You have made us for yourself, O Lord, and our heart is restless until it rests in you" (Augustine, Confessions, Lib. 1,1-2,2.5,5; CSEL 33, 1-5).

Such a concept is by no means abstract. Contrary to many "realistic" theories, it leads the analyst to the study of real processes in which one focuses on the technological, economic and social development of nations. There is no such thing as unlimited development in the state of nature but it can be considered if one refers to natural order. It is possible to describe the demographic dynamics, which seems to be relatively positive from the perspective of the whole of mankind but not necessarily in the case of Russia and the West. It is not difficult to estimate life expectancy, infant mortality, the length of time a citizen must be employed to afford one square foot of real estate or the participation in NCO. Even the level of happiness becomes an object of sociological research (Левада-Центр, 2014). In other words, it is relatively possible to estimate to what extent a state or a certain system meets the expectations of regular and, what is no less important, unrestricted 
development of the citizens, so that they continually get healthier and happier but also increasingly motivated to reach the next stages of health, satisfaction, wealth and happiness.

There is no doubt that such categories (as mentioned above) can be expressed only by means of indirect statistical indicators. However, if compared to the revolutionary imperatives such as equality, brotherhood or social justice, they still seem quite scientific.

If one looks critically at the categories of natural order and those of the revolution, it is possible to discern a specific relation between them since the revolutionary thinking is by no means autonomous; it is a dark shadow of the natural search for goodness. Let us have a look at the basic oppositions which are relevant to the natural order paradigm and the new proposal promoted by Bolshevism. For a reasonable simplification, we will use the term "traditional" for the categories of the natural order paradigm and the adjective "revolutionary" to express the ones that underlie the revolutionary thinking.

1. The traditional opposition of prosperity versus poverty was replaced by the revolutionary one of social justice versus social injustice.

2. The traditional opposition of God-given individual freedom versus slavery (created by imperfect man) was replaced by the revolutionary one of freedom as consciousness of necessity versus class unconsciousness.

3. The traditional opposition of political liberty - totalitarianism was replaced by the revolutionary one of liberation of the proletariat versus social oppression.

4. The traditional opposition of human dignity - degradation (animalization) was replaced by the revolutionary one of communist relations of production versus historically backward relations of production. The individual dignity for the Bolsheviks was only a product of the superstructure (comp. Bochenski, 1963, pp. 119-120). 
5. The traditional opposition of legal equality versus legal inequality was replaced by the revolutionary one of equality in the access to goods versus inequality in the access to goods.

6. The traditional opposition of respect for property versus theft was replaced by the revolutionary one of liberation from private property versus kulak mentality.

7. The traditional opposition of respect for individual life and health versus murder/disrespect for health was replaced by the revolutionary one of respect for the "collective man" (individual lives were obviously unimportant) versus disrespect for the interests of the proletariat (Fülöp-Miller, 1965, pp. 7-8).

8. The traditional opposition of solidarity versus discord was replaced by the revolutionary one of class consciousness (comp. Goldman, 1971, pp. 69-70) versus class treason.

9. The traditional opposition of competition for perfection versus destructive uniformity was replaced by the revolutionary one of collective work (Stakhanov ethic) versus sabotage.

10. The traditional opposition of equal opportunities versus unequal opportunities was replaced by the revolutionary one of the satisfaction of needs vs failure to satisfy needs (according to the belief that "all stomachs are created equal").

11. The traditional opposition of highest harmony versus chaos was replaced by the revolutionary one of classless society versus class struggle.

12. Last but not least, the traditional opposition of nobilitas naturalis versus populus naturalis was replaced by the revolutionary one of the avant-garde of the proletariat (the Party) versus the Proletariat itself (the not entirely selfconscious subject of historical development).

As observed in Toynbee's Study of History, after some time the creative minority inevitably turns into the dominant minority (Toynbee, 1939, pp. 35ff, 445ff, 459ff) However, the natural elite is not a closed and established class. It is rather a constantly 
changing group where some people are continually replaced by others as a result of the functioning market. The avant-garde of the proletariat is a different story: the party members become state officials and are able to establish laws that protect them from natural competition (Đilas, 1957).

This short overview opens the door to generalization: one may realize that the new revolutionary oppositions can be described as deconstructed forms of the traditional ones. We decided to categorize the revolutionary paradigm in such a way because the Russian Revolution turned against many more values than the ones represented by the old regime. The Bolsheviks and other radical revolutionaries tried to demolish any inequality without reflection about the natural character of the emergence of elites and avoided considerations about the temporariness and randomness of injustice in their own lives and in the whole Russian Empire.

Finally, there is an obvious need for a glimpse into the relation between the Russian Revolution and natural order in the pragmatic perspective. An objective and just evaluation of the revolution and the following Soviet period in Russian history is hardly possible. As stated in the second chapter of our book, Russia still looks at itself through the prism of its Soviet past and is by all means under the impression of the trauma that arose after the collapse of the red empire.

In many bitter ways, the Russia of the $21^{\text {st }}$ century is still a shadow of its previous greatness both in the material and moral dimensions. According to Maxim Kalashnikov, who resorts to Victor I. Petrik's sociological research, the Post-Soviet anthropological type is much more passive than its Soviet predecessor. Today's Russia has become a state where the leading role both in ideology and economy belongs to "ruminants" (жвачные) - people who do not believe that a technological breakthrough is possible in their country: everything important has already been invented and even if there is a chance of some new ideas, they will appear in the West rather than in Russia (Калашников, 2014, p. 188). 
This nostalgic tone, however, seems to be justified only if one compares the Soviet times with the period of the Russian Federation. A comparison of the economic dynamics of the Russian Empire in the last decades of its existence with analogous data concerning the USSR leaves no doubt. No one could neglect the obvious achievements in education, science or health care in the Soviet Union. Nevertheless, it is essential to remember that GDP per capita, if related to the level of more advanced countries, fell from $28 \%-30 \%$ in 1913 to $16-18 \%$ in 1990 (Meliantsev, 2004 , pp. 106, 120). In other words, the balance of the old times was more impressive.

The problem obviously lies not only in the disputable achievements in the country's economy. Under the early Bolshevik regime and in the USSR, the inhabitants of the huge territory experienced unprecedented terror. There are various estimates as to the number of victims in the Soviet Union. Hosking (2001, p. 469) supposes that only in the 1930s the death toll reached about 10-11 million. If one takes into account the victims of the Red Terror, the unnecessary casualties during WW2 and the prisoners of the Gulags, we are left with the image of a demographic disaster. Ruined health, broken personalities, and a slave mentality of the Homo Sovieticus are the next signs of destruction that became the daily bread of millions.

Can the successor of the USSR be treated as a country that rejected all Soviet curses? It seems that pessimistic opinions prevail among average Russians. A clever explanation of the economic and civilizational failure was provided by Andrei Piontkovsky, who makes a distinction between the economic reforms in Russia and Central Europe. In the latter, privatization was clearly "unjust" since many of the previous managers came into property that had never been theirs in the legal sense. However, they took care of it anyway and were able to act in the circumstances of the free market. This led to natural competition, where the "unrighteous" 
brainy leaders pushed the less efficient ones out of the market. The same was expected in Russia but the result was different. The "principle of injustice" was not limited to the moment of original distribution but was continued in the next two decades. The new formation is continually mutating, remaining neither capitalist nor socialist. The oligarchs became mandarins rather than business people and managed to rob Russia of enormous wealth, which then appeared on their accounts beyond the borders of the Eurasian Economic Union (Piontkovsky, 2011, p. 392).

The Russian Revolution not only became a tragically consistent attempt to realize a utopian gnostic vision, based on radical oppositions, but also a far-reaching process in which, willingly or not, the new distinctions appeared to be a deconstructed version of those which are dictated by the logic of Natural Order. In this sense the legacy of the Russian Revolution is a gigantic lie, a false mirror which still torments the citizens in the largest part of the post-Soviet area: the official rhetoric remains populist but the state - strictly oligarchic. The idea of international diversity and multipolarity is a hidden concept of leaving a great number of nations without security and the rejection of today's internal and international leadership is only a hidden and selfish form of promoting another order of much more severe inequality. The idea of brotherhood justifies the invasion of brothers. The declared necessity of strength is in fact a desperate attempt to regain lost respect. New legal regulations are a result of fear rather than of self-confidence: the gnostic vision of us as the light side of the force and the internal and foreign challenge as a destructive element whose activity has to be averted, is another attempt to build oppositions that have nothing in common with natural order, where everybody is invited to compete and cooperate at the same time. 